\title{
'n Ondersoek na 'n gemeente se aanbiddingsvoorkeure om lidmaatdeelname ten opsigte van sang en musiek te bevorder binne die raamwerk van ses aanbiddingsmodelle
}

\author{
Brits, Hans J \\ Vaal University of Technology \\ hansb@vut.ac.za
}

\begin{abstract}
Examining the worship preference of a congregation in order to enhance worshippers' participation in song and music within the framework of six worship models

The important role of music and singing within the dialogue of the liturgy should never be underestimated. It is imperative for any congregation to understand its members' preference to liturgical song and music. Knowledge gained from this understanding can assist congregations to make informed decisions with regard to the different forms and genres of church music and hymns which may enhance worshippers' participation. This article reflects on a study that was conducted at a Dutch Reformed congregation to investigate the worship preferences with specific reference to church music and hymns, based on six worship models. The study is performed from a reformed perspective and can be used as a conceptual framework by congregations that have a similar need to ensure improved worship participation.
\end{abstract}

Key words

Formal liturgical worship; traditional hymn-based worship; charismatic worship; emerging worship; blended worship; liturgical singing 
"Als één man spreekt de kerk haar lof uit voor Gods aangezicht." (Milo: 1946)

\section{Konteks van die ondersoek}

Hierdie artikel besin oor 'n ondersoek wat in die Nederduits Gereformeerde (NG) Gemeente Oosterlig, Vanderbijlpark, geloods is met die doel om hierdie gemeente se aanbiddingsprofiel en meer spesifiek die lidmate se voorkeur vir musiek en sang in die erediens beter te verstaan. Die kerkraad van bogenoemde gemeente het die kommer met baie lidmate gedeel dat dit voorkom dat nie alle lidmate se voorkeure wat musiek en sang betref, ten volle in die erediens aangespreek word nie. Die gemeente gebruik die Liedboek van die Kerk (2001) as primêre liedbundel tydens eredienste.

Die behoefte aan 'n studie oor die gemeente se sang en musiekvoorkeur tydens eredienste is bevestig deur spekulering binne die gemeente dat die lid mate wat die gemeente verlaat het, dit heel waarskynlik gedoen het omdat hulle erediens deelname deur musiek en sang in Oosterlig beperk word. Die kerkraad van die gemeente is oortuig daarvan dat lidmate se behoefte aan aktiewe deelname aan die erediens, en in hierdie geval spesifiek wat deelname deur middel van sang en musiek betref, nie onderskat mag word nie. Hierdie aanname is in lyn met Barnard (1985: 582) se standpunt oor deelname van gelowiges aan die erediens naamlik dat indien daar nie in 'n erediens gesing word nie, 'n wesentlike deel van die erediens ontbreek.

Alhoewel die Liedboek van die Kerk (2001) as 'n vaste liedrepertorium in die gemeente gebruik word, blyk dit dat nie alle lidmate se spiritualiteitsvoorkeure deur die liedversameling ten volle aangespreek word nie. Hierdie aanname van die Liedboek staan in kontras met Kloppers (2003:80) se opmerking dat die Liedboek van die Kerk se “ ... pluraliteit voorsien in uiteenlopende behoeftes ten opsigte van die erediens, en die verskillende persoonlikhede en generasies in die erediens". Om die verskillende persoonlikhede en generasies binne 'n gemeente te verstaan, is 'n ondersoek na die verskillende spiritualiteite binne die gemeente nodig. Hierdie verskillende soorte spiritualiteite bestaan naas mekaar en bepaal in 'n groot mate die sang en musiekvoorkeur van lidmate bepaal. Calitz (2011:324) verwys na hierdie spiritualiteite binne 'n gemeente as die “... richness of the congregation”. 
Van die jonger lidmate het tydens informele gesprekke met kerkraadslede genoem dat die orrelmusiek in Oosterlig die gemeente laat "trek" en "oudmodies" is en pas by die karakter van die gemeente, wat hoofsaaklik uit ouer lidmate bestaan. Hierdie opmerking sluit aan met De Klerk (1999:315) se stelling dat tradisionele sang en musiek maklik afgemaak kan word as oorblyfsels uit die verre verlede en as simbool van dit wat al lankal "dood" is. Die kerkraad van bogenoemde gemeente het'n praktiese teoloog versoek om 'n ondersoek na die sangvoorkeure van die NG Gemeente Oosterlig te loods.

Omdat musiek binne die erediens slegs binne die konteks van die liturgie waarbinne dit funksioneer verstaan kan word, is in hierdie studie Paul Basden (2004) se werk oor ses verskillende aanbiddingsbenaderings in Noord-Amerikaanse kerke as raamwerk gebruik. Basden se studie reflekteer op die verskillende aanbiddingsvorms soos wat dit deur ses eksponente van die aanbiddingsbenaderings beskou word. Die ses benaderings is die Formeel-liturgiese (FLA), Tradisionele Liedboekgebaseerde aanbidding (TLGA), Kontemporêre aanbidding (KA), Charismatiese aanbidding (CA), Gemengde aanbidding (GA) en Opkomende, of Ontluikende aanbidding (OA). Hierdie artikel besin inleidend oor literatuur wat betrekking het op gemeentesang en musiek in die algemeen. Dit bespreek Basden se ses aanbiddingsmodelle en hoe dit aangewend is om die NG Gemeente Oosterlig se aanbiddingsprofiel beter te verstaan. Dit blyk uit die studie dat die gemeente ten opsigte van sy aanbiddingsvoorkeure besig is om weg te beweeg van 'n TLGA na 'n GA en KA. Die studie mag dien as raamwerk vir gemeentes wat met soortgelyke uitdagings te kampe het en 'n behoefte het om 'n ingeligte besluit te neem ten opsigte van 'n gemeente se sang en musiek.

\section{Gemeentesang en -musiek}

Vir die doel van hierdie studie is dit noodsaaklik om die konsep "gereformeerd" oorsigtelik te bespreek omdat die aanbiddingsvoorkeure van 'n gemeente binne die reformatoriese tradisie bestudeer word. Die konsep gereformeerd in hierdie studie sal beteken dat die vaste beginsels soos die betroubaarheid van die Woord, geloof in Jesus Christus as die geïnkarneerde Seun en Verlosser en die genade van God die Vader as uitgangspunte gebruik word. Soos reeds genoem, kan erediensmusiek slegs 
binne die konteks van die liturgie waarbinne dit funksioneer verstaan word. Die konsep liturgie word deur Barnard (1985:52) gedefinieer as “... al die woorde en handeling van die volle erediens ... ook die fundering en vormgewing van die erediens, die gebede, liturgiese formuliere, die kerklied ...die hele dinamiek van die erediens". 'n Sinvolle "gereformeerde" erediens word volgens Müller (1990:53) beskou as 'n erediens met 'n goed verantwoorde liturgiese orde wat op suiwer teologiese grondslag rus. Volgens Du Plessis (2004:116) is een van die kenmerke van 'n gereformeerde erediens 'n ordelike verloop wat uiting vind binne die raamwerk van 'n liturgiese orde. Cilliers (1998:77) beskou gereformeerde liturgie as eredienste met inhoud, skoonheid en eietydsheid in diens van die Waarheid. Die Skrif word daarom beskou as gesaghebbend aangesien dit in 'n Goddelike oorsprong gewortel is en daarom is dit betroubaar en genoegsaam tot heil. Volgens Heyns (1981:32) dui die genoegsaamheid van die Woord daarop dat daar " ... geen objektiewe aanvulling ... of subjektiewe aanvulling" nodig is nie. Vanuit 'n gereformeerde perspektief is die Skrif die enigste gesaghebbende bron vir kennis van God se openbaring.

Binne'ngereformeerde konteks is dit in dieliturgie waar dieverbondskinders 'n geleentheid gebied moet word om deur middel van gebed, musiek en kerksang te antwoord op Gods Woord." Sang vergestalt deur die eeue die lofuiting van gelowiges as hulle weerwoord, maar dit is ook meer as slegs blote respons, dit is 'n verkondigingsmoontlikheid (Kloppers 2003:67; Kloppers en Dreyer 1994:583-609). Dit gaan nie oor God wat spreek nie maar "wie" en "wat" God is. Deur die lied word nie net metafore gebruik oor wie God is nie maar word ook waarhede oor die skepping, sonde, vergifnis, vryheid en die hiernamaals wat aanvullend tot die gesproke woord is. Binne 'n gereformeerde konteks dink gelowiges binne die erediens na oor God en word in kerksang gesoek na woorde en beelde wat in lyn staan met die Skrif. Kerksang en musiek verskaf gelowiges beelde of metafore om die waarheid van die evangelie beter te verstaan. Deur middel van godsbeelde wat in kerksang voorkom vind 'n weergawe dus plaas van "wie" of "wat" God vir die gelowige is. God is byvoorbeeld in die erediens die teenwoordige God met 'n "lewende aanwesigheid" (Smit 2009:99). Dit is deur sang dat lidmate nie net in 'n ontmoetingsgebeurtenis antwoord nie maar ook God se goeie dade onderling verkondig deur getuienis te lewer. Daarom stel Kloppers $(2003: 68,69)$ dit duidelik dat die gemeentelied wat in die Nuwe Testament gebruik is, gekenmerk word met 'n dubbele gerigtheid, 
naamlik "vertikaal en horisontaal". Johansson (1998:38) wys daarop dat die beeld van God in kerkmusiek na vore moet kom en nie die beeld van die wêreld óf die beeld van Satan nie. Sang en kerkmusiek wat onvoorbereid aangebied word, of die inhoud wat nie in lyn staan met die vyf Solas van die Reformasie nie, of musiek wat nie van musikale hoë waarde is nie, stel die gereformeerde identiteit van die Kerk in gevaar en skep vir aanbidders 'n negatiewe beeld van God.

Vanuit 'n gereformeerde beskouing is God die Inisiator van die erediens wat sy gemeente as gemeenskap van gelowiges geroep en saambring het om hul hul geloof te bou, toe te rus, te versterk en weg te stuur om tot sy eer te lewe. Binne die erediens is handelinge soos gebede en gemeentesang, Woordverkondiging en die bediening van die sakramente bedoel om onderlinge gemeenskap te vorm en versterk. Lidmate se aktiewe deelname vorm deel van die liturgie en is noodsaaklik vir effektiewe Woordverkondiging. Kloppers en Dreyer (1994:583-609) stel dit duidelik dat indien nie alle gemeentelede aktief aan gemeentesang kan deelneem nie, Woordverkondiging nie meer tot sy reg kom nie. Verkondiging vind immers nie net deur die gesproke woord plaas nie maar ook deur die gesonge woord (Kloppers 2003:68). Kloppers (2003:67) gebruik die konsep "geloofskommunikasie" wat die "mens as geheel in 'n veranderende geestesklimaat" moet aanspreek en betrek om sodoende die volle omvang van die evangelie kreatief te kommunikeer.

'n Tradisionele gereformeerde erediens volg 'n vaste struktuur. Daar is 'n duidelike wisselwerking tussen die liturg en die gemeente en die liedere wat saam met byvoorbeeld orrelbegeleiding gesing word, hierdie sang is ten opsigte van taal en musiek van hoë gehalte (Du Plessis 2004:33). Volgens Barnard (1985:403) moet gemeentesang "die hele gemeente" omvat en moet elke lidmaat "op 'n direkte wyse" (Barnard 1985:5) deur sang en musiek aangespreek word. 'n Aanname kan dus gemaak word dat indien die hele gemeente nie deur sang en musiek in die erediens aangespreek word nie, dit 'n negatiewe effek op Woordverkondiging mag inhou. Sang en musiekvoorkeure van lidmate binne 'n bepaalde gemeente is ook nie staties nie maar verander voortdurend. Kloppers (2003:65) merk daarom op dat gereformeerde lidmate se behoeftes ten opsigte van musiek in die erediens nie noodwendig dieselfde as dertig jaar gelede is nie. Daar is 'n voortdurende gees van vernuwing betreffende musiekvoorkeure en style in gemeentes (Wepener 2009). 
Wepener (2009) verwys na die hedendaags tendens rondom die erediens waar daar 'n groter soeke en verlange is na 'n ervaring van God se teenwoordigheid. Postmoderniteit is die basis van die nuwe geslag se denke en besluite en skep ruimte vir 'n nuwe godsbesef (Du Plessis 2004:16). Die kerk funksioneer lankal nie meer binne 'n moderne wêreld nie, maar beleef die impak van 'n postmoderne wêreld (Dingemans 1996:117) wat ook sekere eise aan sang en musiek stel. Volgens Smit en Vorster (2000:525) wil die postmoderne gelowige "vanuit 'n koue, hoogs kompeterende wêreld 'n toevlug vind in die erediens". Om hulle binne hierdie veranderende paradigma te kan handhaaf, het verskeie gemeentes binne die gereformeerde tradisie reeds nuut oor aspekte soos liturgie, en daarmee saam sang en musiek in die erediens nagedink en soms die nodige aanpassings gemaak. Daarom het die landskap van die kerklied en die liturgie van die NG Kerk in sekere gemeentes reeds "dramaties verander" (Pieterse 2011:47).

As deel van 'n tydsgewrig van tegnologie, is dit geensins vreemd dat gemeentes tydens eredienste elektroniese apparate, digitale skerms en dies meer gebruik nie. Baie gemeentes gebruik begeleidingsinstrumente wat nie net die klassieke kerkorrel insluit nie, maar ook tromme, klassieke kitare, elektriese kitare, baskitare, tamboeryne, klaviere, elektroniese klaviere, trompette, harpe, fluite en saksofone (Calitz, 2015). Hierdie instrumente word in baie gemeentes gebruik om die tradisionele kerkmusiek wat met 'n orrel geïdentifiseer word, te vervang met sogenaamde kontemporêre musiek. Die sangrepertorium van baie gemeentes binne die NG Kerk bestaan op die oomblik uit 'n groot variasie liedere waarvan sommige oorgeneem is uit nie-gereformeerde tradisies as 'n poging om die sang- en aanbiddingsvoorkeure van soveel moontlike lidmate aan te spreek. Hierdie liedere word as "vrye liedere" beskou, dit wil sê liedere wat nie amptelik deur die kerk, soos in die geval met die Liedboek van die Kerk (2001), gesanksioneer is nie. Baie gemeentes gebruik in hierdie verband met groot vrug die FLAM- en VONKK-versamelings wat Afrikaanse "gospel" en kontemporêre musiek saam met ekumeniese kontemporêre musiek insluit.

Nuwe terme wat in gemeentes ten opsigte van musiek en sang gebruik word sien die lig, so byvoorbeeld die konsep "musiekbediening". Hierdie konsep verwys gewoonlik na 'n aanbiddingsleier wat met 'n musiekinstrument, of saam met 'n orkes, of 'n begeleidingsgroep, die sangbegeleiding hanteer. 
Die orrel word in sommige gemeentes nie meer gebruik nie, of dit word nie noodwendig as die primêre musiekinstrument gebruik nie.

\section{Ses aanbiddingsvorme}

Ses aanbiddingsmodelle of aanbiddingsvorme word in Basden (2004) se boek "Exploring the Worship Spectrum" bespreek. Hierdie ses strominge van kerkmusiek vorm grootliks die teoretiese'n gemeente se "kleinverhaal". Die volgende ses kundiges wat in bogenoemde boek aan die woord kom is Paul Zahn (FLA), Harold Best (TLGA), John Horness (KA), Don Williams (CA), John Webber (GA) en Sally Morgenthaler (OA).

\subsection{Formeel-liturgiese aanbidding (FLA)}

Die FLA word deur PaulZahl(2004), 'n kennervan hierdie aanbiddingsvorm, beskryf as Bybelgesentreerd en gebaseer op die gereformeerde Sola Scriptura beginsel van die reformasie (Zahl 2004:26). Tydens die erediens gee die FLA dus voorrang aan die Woord van God. Daarom beskou Zahl die FLA as "Bible-based verticality, which is another way of saying formal-liturgical worship" (Zahl 2004:23). Musiek in FLA is voorgeskrewe musiek vanuit die westerse Christelike kanon en funksioneer binne 'n liturgiese raamwerk. Musiek in FLA kan nie buite hierdie raamwerk verstaan word nie. Zahl verwys na die FLA as aanbidding wat "Bybelse waarheid" verkondig (Zahl 2004:25) en as Godgerigte aanbidding beskou kan word. Zahl wys ook daarop dat FLA nie prediker-geörienteerd is nie. Volgens Zahl het baie Evangeliese en Protestantse gelowiges FLA verwerp omdat dit op grond van dié aanbiddingsvorm se formele aanbiddingstyl, deur eeue heen verkeerdelik met Roomse Katolisisme of Anglikaanse Katolisisme binne 'n Noord-Amerikaanse konteks geassosieer is.

In hoofstuk een beskryf Paul Zahl (2004:23) die FLA as 'n "waardige" aanbidding wat nie bepaal word deur die "spontaneity of the moment of the officiant" nie, maar eerder 'n voorgeskrewe aanbiddingsvorm is: "prescribed worship, service that is required for a given occasion". "What we believe determines how we pray," skryf Zahl (2004:25). Die nagmaal word in die FLA as 'n sentrale element beskou. Daar word streng gelet op die Bybelse waarheid ten opsigte van hierdie sakrament. Musiek wat tydens die FLA gebruik word, word as tipiese liturgiese musiek beskou: 
“... we need music in order to worship God, disclosing the archaeology of our temperament in non verbal communication upward” (Zahl 2004:29). Musiek binne die FLA sal in die meeste gevalle van 'n hoë gehalte wees en "married to words of substance" (Zahl 2004:29). Musiek in FLA dien as katalisator vir die emosies van aanbidders en lewer 'n bydrae tot geestelike verdieping en -ontwikkeling.

Kritiek wat deur die ander vyf outeurs teen die beskouings van FLA gelewer word, is dat die benadering ongelukkig die werking van die Heilige Gees beperk. FLA kom volgens die ander outeurs maklik as koud voor. FLA mag daarom deur vreemdes as minder gebruiksvriendelik beskou word, wat sal inhou dat iemand uit 'n nie-liturgiese agtergrond dit moeilik sal vind om by 'n diens van FLA in te skakel. FLA het elemente van 'n 'tradisionele' gereformeerde erediens in Suid-Afrika naamlik dat 'n vaste struktuur tydens die erediens gevolg word, dat dit "Bybelgesentreerde" aanbidding is en dat die liedere en musiek van musikale hoë gehalte is. Volgens Calitz (2015:15) herinner FLA binne'n Suid-Afrikaanse konteks ons onder andere aan die Anglikaanse Kerk.

\subsection{Tradisionele Liedboekgebaseerde aanbidding (TLGA)}

Harold Best beskryf in hoofstuk twee van die boek Exploring the Worship Spectrum (Basden 2014) die TLGA. Volgens Best is die mens aanbiddend geskep en nie geskep om te aanbid nie. In TLGA word daar hoofsaaklik van liedboeke in gedrukte vorm tydens eredienste gebruik. Die TLGA liedboek word deur Best beskou as 'n tydelike dienaar van die Skrif wat maar net deur mense geskep is. Die liedboek het 'n diversiteit ten opsigte van musiekstyle en is die produk van 'n lang historiese stryd om buite-bybelse tekste te sing. Best se bespreking van TLGA laat die klem hoofsaaklik op liriek en in 'n mindere mate op musiekstyl val. Kenmerkend van die gebruik van 'n liedboek is dat dit voorsiening maak vir gedeeltes wat gesing word, en ook dele wat tydens die erediens deur die gemeente as 'n respons uitgespreek kan word. Drie gebede vorme word in TLGA gebruik naamlik kortgebede, gebede deur die gemeente en pastorale gebede wat namens die gemeente gelewer word. Volgens Best bevorder die liedboek persoonlike toewyding. In TLGA word instrumentele musiek tydens dienste gebruik. Die liedboek kan ook Skrifgedeeltes, preke en bogenoemde gebede bevat. Net soos die FLA word die nagmaal in die TLGA op 'n kontinue basis gevier. Die liturgie van TLGA maak ook voorsiening vir offergawes. 
Die musiek en teks van die liedboeke is, soos ook in die geval van FLA, van hoë gehalte en mag ook ook bladmusiek bevat vir musiekinstrumente wat tydens die musiekbegeleiding gebruik kan word. Best (2004:67) wys daarop dat TLGA ongelukkig die kragtige werking van die Heilige Gees kan demp. Kritiek wat vanuit die ander vyf benaderings uitgespreek word, sluit ook in dat TLGA baie "selfvoldaan" voorkom. TLGA mag ook deur lidmate ervaar word as 'n aanbiddingsvorm wat oudmodies is en nie altyd tred hou met vooruitgang nie, omdat, ten spyte van die feit dat ons binne 'n tegnologies gevorderde eeu leef, belangrike elemente van die eietydse kultuur (byvoorbeeld populêre musiek, digitale hulpmiddels) nie ondervang word nie. Soos in die geval van FLA plaas ook die TLGA meer klem op die aanbidder en minder op besoekers wat buite hierdie aanbidding staan. Binne 'n Suid-Afrikaanse konteks kan die Gereformeerde kerke volgens Calitz (2015:15) beskou word as TLGA. Tog moet genoem word dat binne die NG Kerk verskillende benaderings, style, repertoriums en aanbiedings naas mekaar gevind word en word die repertoriums van baie NG gemeentes nie meer tot die Liedboek van die Kerk (2001) beperk nie. Daar is alreeds by baie NG gemeentes tekens van 'n wegbeweeg vanaf TLGA na KA en GA, veral ten opsigte van die gebruik van moderne musiekinstrumente, die vryelied en die aanwending van moderne tegnologie. Dit is nie 'n vreemde verskynsel om tydens eredienste van NG gemeentes begeleidingsinstrumente te vind wat strek vanaf die klassieke kerkorrel tot moderne musiekinstrumente nie (Caltiz 2015:18). Baie gemeentes akkommodeer ook verskillende generasies, spiritualiteite en behoeftes deur op Sondae verskillende eredienste aan te bied.

\subsection{Kontemporêre aanbidding (KA)}

Die uitgangspunt van KA is dat God interaksie met aanbidders begeer en dat kontemporêre musiek, eerder as die sing van tradisionele liedere of responsoriese spreke van gemeentes, hierdie interaksie fasiliteer. Dit is hoofsaaklik die musiekleier se verantwoordelikheid om hierdie ervaring met God deur middel van sang en musiekbegeleiding te skep. KA word daarom as musiekgedrewe aanbidding beskou. Horness (2004:105) is van mening dat 'n instrument soos die orrel nie meer'n appel op die jonger en die eietydse aanbidder maak nie. In KA word die musiek tydens gemeentesang gemaak deur voorsangers en 'n orkes met musiekinstrumente, soos tromme en kitare, en word daar ook van tegnologie soos dataprojektors 
en mikrofone gebruik gemaak. In KA word nuwe liedere soms geskep. Alhoewel nuwe liedere soms gemaak word vir gebruik tydens KA, het baie van hulle 'n tradisionele oorsprong en moet daarom verwerk word om by die idioom van die aanbidders aan te pas. In KA is die doktrinale kwessies onbelangrik, die primêre doelwit is om behoeftes van die lidmate te bepaal en om kultuur sensitief te wees.

John Horness (2004) wys daarop dat die klem in KA veral geplaas word op die aanbidder se ervaring met God. KA bring die aanbidder in kontak met God en fasiliteer 'n tweerigtingkommunikasie tussen God en gelowige. Horness beskou KA as die beste manier waardeur die hart van die aanbidder by die erediens betrek kan word. Volgens Horenss is KA 'n aanbiddingsvorm waartydens outentieke aanbidders (Horness 2004:109) God op 'n outentieke wyse aanbid (Horness 2004:110). Kritiek deur die verteenwoordigers van die ander vyf benaderings teen $\mathrm{KA}$ is veral gerig op die oordrewe klem wat, as 'n soort voorvereiste vir aanbidding, geplaas word op die aanbidder se gevoel en ervaring. Skerp kritiek word ook deur die ander outeurs gelewer op Horness se aanspraak dat KA die beste manier is om 'n ontmoeting met God te fasiliteer. Horness se siening dat die orrel nie meer deurdie moderne mens as geskik beskou word vir aanbidding nie, word ook deur die ander verteentwoordigers van die aanbiddingsvorms skerp gekritiseer. Anders as die TLGA en die FLA is KA egter meer toeganklik vir buitestaanders. Binne 'n Suid-Afrikaanse konteks beskou Calitz (2014) die Vrye (onafhanklike) kerke en die gemeentes wat vanuit die hoofstroomkerke ontstaan het as KA (en GA).

\subsection{Charismatiese aanbidding (CA)}

Don Williams (2004) bied in sy bespreking van CA in hoofstuk 4 van Exploring the Worship Spectrum 'n kort historiese agtergrond van dié aanbiddingsvorm. CA het sy ontstaan te danke aan die Amerikaanse Pentekostalisme, wat ook in die Episkopaalse en die Rooms-Katolieke tradisie ingang gevind het. CA ontstaan binne die konteks van die NoordAmerikaanse politieke en kulturele krisis van die jare sestig. CA word geassosieer met 'n nie-kritiese en eenvoudige geloof waar groot klem op die doop met die Heilige Gees en evangelisasie geplaas word.

CA is gebaseer op die trinitatriese teologie en is volgens Williams (2004:139) 'n aanbidding waar die gawes van die Heilige Gees sigbaar word tydens 
lofprysings wat gerig word om God se magtige dade te prys. Alhoewel glossolalie kenmerkend is van hierdie aanbiddingsvorm, is daar ook 'n beweging binne die CA wat nie meer primêr klem op die manifestasies van die Heilige Gees lê nie. Aanbidders is tydens die CA aktief betrokke by die erediens, en tydens sang en musiek word die hande onder andere opgehef en vind manifestasies van die krag van die Gees plaas. Volgens Williams (2004:147) word in CA 'n vyffase-raamwerk gebruik. Hierdie raamwerk bevorder 'n Godgesentreerde aanbidding wat gekenmerk word deur geestelike diepte en kontemporêre relevansie. Die vyffase-raamwerk word gebruik om groter intimiteit met God te ervaar. Volgens die raamwerk word daar eers gefokus op 'n oproep tot aanbidding waarop dan betrokkenheid, verhoging, bewondering en sang volg. Williams is van mening dat die CA nie, soos die ander aanbiddingsvorme wel, tydens aanbidding die Heilige Gees onderbeklemtoon nie. Tydens die laaste segment van die erediens vind gebedsbediening as deel van die liturgie plaas.

Kritiek van die ander verteenwoordigers teen hierdie aanbiddingsvorm, is dat die liedere wat gesing word teologies oppervlakkig is met 'n oordrewe klem op sentimentaliteit. CA kan ook nie aanspraak maak op spontane sang nie, omdat die sang binne 'n vaste struktuur plaasvind. Dit wil ook voorkom asof daar tydens CA groter klem op die Heilige Gees val, terwyl daar in 'n minder mate op aspekte soos heiligmaking en verlossing gefokus word. Binne 'n Suid-Afrikaanse konteks kan die charismatiese bewegings in Suid-Afrika beskou word as CA (Calitz 2015:15).

\subsection{Gemengde aanbidding (GA)}

In hoofstuk 5 definieer John Webber (Basden 2014: 178) GA as "a synthesis of the liturgical and contemporary worship renewal movements of the twentieth century". GA het'n sterk Euro-Amerikaanse aanbiddingskarakter, wat dit dalk minder effektief vir 'n Afrika-aanbiddingskultuur maak (Basden 2004: 192). Webber (2004:179) gebruik die term "konvergensie" as sinoniem vir "gemengde aanbidding". In hierdie artikel word Calitz (2015:4) se "blended worship", gemengde aanbidding dus, met verwysing na die Suid-Afrikaanse konteks gebruik ten einde onderskeid te tref met konvergensie aanbidding binne 'n Noord-Amerikaanse konteks.

Volgens Webber het GA as 'n liturgiese hernuwingsbeweging in die jare sestig in Noord-Amerika ontwikkel. Hierdie beweging is later met 
die Kontemporêre Hernuwingsbeweging gekombineer. Die doel van die Kontemporêre Hernuwingsbeweging is om veral die teologie van aanbidding, die rol van musiek in die liturgie, die deelname van die gemeente, en ook die Christelike jaar te herstel. Webber (2004:179) beskryf "blended worship" as "at its best as suubstance and relevance, truth and experience, divine and human". Kenmerkend van die GA is die liturgiese struktuur van versameling, die bediening van die Woord en die Tafel, en die uitsending. Verskeie tradisies vorm later deel van die GA, waaronder die Gereformeerdes, Anabaptiste, Kwakers en die Liturgiese tradisies. Vir die doel van hierdie studie is die GA se ywer om 'n groter deelname onder aanbidders te bewerkstellig, belangrik. Musiek in die GA sluit liedere uit verskillende denominasies in byvoorbeeld liedere uit verskeidenheid "hymns", "chorusses", asook kontemporêre musiek. Hierdie musiek is eie aan die kultuur en demografie van die gemeente en is op maksimum deelname ingestel. Kunstenaars word die vryheid gebied om deur middel van kuns die evangelie uit te druk. Volgens Webber (2004:178) vul "blended worship" die leemte wat formele sowel as kontemporêre aanbidding laat. Volgens Webber is daar 'n leemte in die "real and vital experience with God" ten opsigte van formele aanbiddingstyl teenoor kontemporêre aanbidding se leemte aan "substance" (Webber 2004:178). GA sluit aan by KA ten opsigte van 'n soeke na die Heilige Gees se werking en 'n outentieke ervaring van God. GA word uitgedruk in die taal van misterie ten opsigte van God die Vader, die taal van simbool ten opsigte van die Heilige Gees en die taal van storie ten opstige van Jesus Christus.

Basden (2004:192-213) wys daarop dat GA 'n Euro-Amerikaanse karakter vertoon wat nie effektief in 'n Afrika-kultuur aangewend kan word nie. Kritiek word ook gelewer ten opsigte van GA se struktuur van aanbidding wat herinner aan 'n Ou Testamentiese eerder as 'n Nuwe Testaemtiese struktuur. Die viervoudige Ou Testamentiese struktuur van GA kom wetmaties voor. GA slaag volgens Basden ook nie werklik daarin om die verskillende generasies te akkommodeer nie. Volgens Calitz (2015:15) kan in 'n Suid-Afrikaanse konteks die gemeentes wat uit die tradisionele hoofstroomkerke ontstaan het, as GA beskou word. Binne 'n SuidAfrikaanse konteks word die konsep "blended worship" soms gebruik om te verwys na 'n kombinasie van musiek wat uit ander tradisies oorgeneem is. Pieterse (2006:1) stel eerder 'n integtrasie van verskillende musiekstyle 
voor waar ouer mense byvoorbeeld nuwe tipe musiek en liedere leer en jonger mense die ryk tradisionele skatte van die gereformeerde tradisie leer ken.

\subsection{Ontluikende aanbidding (OA)}

Sally Morgenthaler (2004) bespreek "emerging worship" wat deur Calitz (2015:5) vertaal word as "Ontluikende aanbidding" (OA). Volgens Morgenthaler (2004) is die kern van OA die "encounters with God born out of a dual passion for a theological rootedness and a deeply transforming connection with a radically deconstructured culture". OA poog om binne 'n posthumanistiese wêreld 'n heilige ruimte vir die postmoderne mens te skep. Die postmoderne mens deel in die gebrokenheid van die posthumanistiese wêreld op grond van die mens se selfbewussyn. OA skep hierdie heilige ruimte vir die aanbidder sodat hierdie gebrokenheid aangespreek kan word. OA bied dus aan die aanbidder ruimte om kontak met God (en Christus) se voortgaande werk te maak.

Volgens Morgenthaler (2004:229) word in die OA gestreef na die aanbidder se belewenis van God op 'n visuele, kinetiese, emosionele en intelektuele wyse. OA fokus op 'n aanbiddingservaring waar sig, reuk, smaak, hoor, voel en reuksintuie betrek word (byvoorbeeld brand van wierook en kerse, sketse wat gemaak word, luister na musiek). Die ervaring van lidmate in die deelname aan aanbidding word vooropgestel, anders as in KA waar 'n erediens "aangebied" word, is die aanbidder in OA aktief skeppend betrokke. Prediking staan nie sentraal in OA nie. Paradoks en elektisisme is kenmerkend in hierdie aanbiddingstyl, Morgenthaler verwys daarna as "radical recontexting" wat "the most noticeable difference between emerging worship and other forms" is (Morgenthaler 2004:229).

In die $\mathrm{OA}$ is daar ook nie 'n vaste orde nie, verskeie handelinge kan gelyktydig plaasvind teenoor die tradisionele liturgiese orde waar lidmate aan dieselfde liturgiese handeling deelneem, of soos Morgenthaler dit stel, "doing the same thing at a time" (Morgenthaler 2004:240). OA kan beskou word as "multisensoriese aanbidding" waar soveel moontlike sintuie in die erediens betrek word deur middel van sang, stilte, prediking en kuns, selfs deur middel van gemeenskaplike etes. Volgens Du Plessis (2004:68) geld die gereformeerde beginsel van orde nie in Multisensoriese Aanbidding nie wat ook ooreenstem met OA binne 'n Noord-Amerikaanse 
konteks. Müller (1990:53) wys vanuit 'n gereformeerde perspektief op die belangrikheid van 'n liturgiese orde wat op suiwer teologiese grondslag moet berus en waarsonder 'n sinvolle erediens nie kan plaasvind nie. Die aanname kan gemaak word dat indien die liturgiese orde na wille keur met 'n struktuurlose erediens vervang word wat boonop nie begrond is op die Skrif nie, loop dit die gevaar dat die gereformeerde identiteit van die Kerk in gevaar gestel sal word.

Die OA wil ontkom aan 'n erediens waar musiek voorskriftelik aangebied word. In werklikheid speel gemeentesang nie 'n prominente rol in die OA nie. Die aanbidding fokus eerder op die mens wat in sy totaliteit moet aanbid (Morgenthaler 2004:229). OA maak in die liturgie gebruik van onder andere gebed, mimiek, geloofsbelydenis, drama, kunswerke (ook graffiti) en nuwe verwerkings van ou liedere. Volgens Morgenthaler ontluik OA iets nuuts in aanbidding. Basden (2004: 231-232) bevraagteken egter die aanname van die OA dat dit iets nuuts laat ontluik. 'n Verdere kritiek is dat dit voorkom asof die Skrif tydens OA minder essensieel word. Kritici betwyfel dit dat dit prakties moontlik sal wees dat OA altyd daarin sal slaag om 'n nuwe liturgie met elke byeenkoms te kan volg sonder dat dit tog maar op een of ander manier in 'n vorm van herhaling sal verval. OA bevat liturgiese elemente van die gereformeerde tradisie en elemente van alternatiewe aanbidding. Noordmans waarsku dat veranderinge aan die orde, rituele, simbole en selfs gebare van die liturgie onwetend dinge kommunikeer wat nie noodwendig in lyn met die gereformeerde leer staan nie. Daar kan nie na willekeur uit verskillende liturgiese tradisies geneem word onder die veronderstelling dat die kerk oor "een erediens" besit nie. Noordmans, soos aangehaal deur Du Plessis (2004:91), waarsku dat dit niks anders as "kultiese smokkelhandel" oor dogmatiese grense heen sou beteken nie.

\section{Metodiek}

Die studie het 'n prakties-teologiese benadering gevolg waar die praktiese teologie beskou word as 'n handelingswetenskap en dui op die kommunikatiewe handelinge wat in diens van die evangelie staan (Firet 1987:260). In die praktiese teologie word die mens se ervaring van God ondersoek en is die objek van die teologie nie God nie, maar in Van der Ven (1988:15) se woorde: "religious praxis (that) can be observed and tested". Die 
konsep praxis verwys na die konkrete handelinge van mense wat in diens van die van die evangelie staan. "Wie vanuit die handelingswetenskaplike perspektief met die himnologie omgaan, kan dus nie anders as om dan ook groot erns met die mens, sy konteks en optrede maak nie" (Van Tonder 2001:8).

Soos reeds genoem is Basden (2004) se ses aanbiddingsbenaderings weens 'n gebrek aan 'n benadering binne 'n Suid-Afrikaanse konteks as teoretiese raamwerk in hierdie studie gebruik. 'n Literatuurondersoek is gedoen en na afloop hiervan is 'n gemengde (kwantitatiewe en kwalitatiewe) metode gevolg om kwantitatiewe data deur middel van 'n vraelys en kwalitatiewe inligting deur middel van onderhoude te verkry. Eksploratiewe stellings (Denscombe 2003:144) is in die vraelys gebruik met hoofsaaklik die doel om die gemeente se sang en musiek voorkeure te bepaal. Data is tydens 'n erediens met behulp van die vraelys ingevorder. Vyf kenmerkende elemente van elke aanbiddingsvorm wat hoofsaaklik met musiek en sang in die erediens verband hou, is as vrae geformuleer en in geen vaste volgorde op die vraelys aangedui. Die data is ontleed en aan triangulasie onderwerp deur middel van 'n reeks onderhoude. Fokusgroepe sowel as een-tot-een onderhoude is met lidmate gevoer wat verskillende ouderdomsgroepe verteenwoordig naamlik 15-25 jaar, 26-39 jaar, 40-50 jaar en ouer as 50 jaar. Die vrae van die vraelys is as bree raamwerk gebruik om indiepte inligting te bekom en om die kwantitatiewe data te verifieer. Die onderhoude is gevoer tot 'n tegniese versadigingspunt bereik is, dit wil sê die onderhoude is gestaak toe die deelnemers geen nuwe inligting kon verskaf nie. Die rasionaal vir die voer van onderhoude word ondersteun deur die siening wat McMillan en Schumacher (2001) voorstaan, naamlik dat navorsing behoort te bepaal in watter mate gevolgtrekkings wat op kwalitatiewe bronne gebaseer word, ook deur middel van kwantitatiewe perspektiewe ondersteun word - en natuurlik ook andersom. Altesaam dertig eksploratiewe stellings is in die vorm van vrae geformuleer (vyf vrae per aanbiddingsvorm). 'n Vyfpuntskaal is gebruik. Die vraelys het ook voorsiening gemaak vir respondente wat verdere skriftelike kommentaar oor musiekbediening wou lewer. Die kwantitatiewe data is deur die navorser verwerk en die resultate is op sirkelgrafieke aangedui. In hierdie artikel word slegs na een sirkelgrafiek naamlik figuur 1 vewys. 'n Volledige verslag met aanbevelings is aan die kerkraad voorgelê en die resultate van die studie is ná 'n erediens deur die navorser aan die gemeente meegedeel. 


\section{Gevolgtrekking en aanbevelings}

Die sirkelgrafiek (sien figuur 1), wys uit dat 'n beduidende persentasie (30\%) van die respondente 'n voorkeur vir Gemengde aanbidding het. 35\% van die respondente het 'n voorkeur vir Tradisionele-liedboekgebaseerde aanbidding, 25\% vir Kontemporêre aanbidding en 10\% vir Charismatiese aanbidding. Die studie toon dat daar geen voorkeur vir OA en FLA is nie, veral nie soos wat dit in 'n Noord Amerikaanse konteks aangebied word nie. FLA binne 'n Noord-Amerikaanse konteks gebruik hoofsaaklik formele sang en musiek, kontemporêre sang en musiek is egter nie gepas nie. Die NG Gemeente Oosterlig is vir jare reeds blootgestel aan 'n liturgiese orde wat van Sondag tot Sondag mag verskil. In die onderhoude is genoem dat van die deelnemers daarom nie saamstem met 'n formele vaste liturgiese struktuur wat gevolg moet word nie (FLA). Van die ouer deelnemers wat aan die onderhoude deelgeneem het, was ten gunste van 'n erediens wat ordelik moet verloop en prediking en sang wat inhoudelik in lyn moet staan met die waarhede van die Skrif (FLA). Die deelnemers aan die onderhoud het nie OA óf 'n Multisensoriese aanbiddingstyl geken nie en het gevoel dat dit maklik tot wanorde kan lei en daardeur die gereformeerde beginsel van ordelikheid kan bedreig. OA binne 'n Noord-Amerikaanse konteks beskou sang en musiek as maar net nóg 'n vorm van aanbidding waar die aanbidder se sintuie betrek word. Die kwantitatiewe data en die inligting wat tydens die onderhoude ingewin is, dui daarop dat die deelnemers sterk voel dat gemeentesang 'n belangrike aanbiddingsvorm naas prediking is. Die aanname kan dus gemaak word dat hulle beskouing nie in lyn staan met OA ten opsigte van die plek van sang en prediking in die erediens nie.

Die data wat deur middel van die vraelys ingevorder is, wys daarop dat veral jonger respondente (in die ouderdomsgroep 15 tot 25 jaar) 'n behoefte het aan ook ander liedere as net dié wat in die Liedboek van die Kerk voorkom. Die onderhoude het gehelp om waardevolle kwalitatiewe inligting in te samel wat in 'n groot mate gehelp het om die data te interpreteer. Tydens die onderhoude het veral die jonger deelnemers genoem dat die Liedboek van die Kerk aangevul moet word met 'n keur van liedere wat van ander denominasies oorgeneem kan word wat dui op 'n voorkeur vir GA. Hulle het ook genoem dat meer liedere uit die versamelings van VONKK en FLAM gebruik moet word. 
Die data wat deur middel van die vraelyste ingesamel is en wat deur middel van die onderhoude getrianguleer is, het getoon dat daar ook 'n beduidende behoefte onder die jonger deelnemers is dat meer kontemporêre musiekinstrumente in die erediens gebruik moet word en nie net slegs die kerkorrel as primêre musiekinstrument nie. Laasgenoemde is deur baie jonger deelnemers beskou as 'n musiekinstrument wat nie geskik is vir kontemporêre musiek nie. Só 'n beskouing stem ooreen met die persepsie van aanbidders wat 'n voorkeur vir Kontemporêre Aanbidding het. Die kwantitatiewe data wat ingesamel is, toon dat ouer lidmate, veral dié in die ouderdomsgroep 50 jaar plus, nie met hierdie stelling saamstem nie en dat 'n beduidende persentasie van hierdie ouderdomsgroep weer 'n groter waardering vir die orrel het. Onderhoude wat met respondente in die ouderdomsgroepe 26-50 jaar plus gevoer is, dui op empatie met die jonger lidmate se voorkeure wat sang en musiek betref wat daarop dui dat die gemeente 'n voorkeur vir GA mag hê. Daar is ook onder hierdie ouderdomsgroep 'n behoefte aan meer kontemporêre musiek en sang, wat die vrye lied insluit. Hulle het 'n groot waardering vir die sing van die vrye lied en verwys in die onderhoude na spesiale dienste waartydens die vrye lied met groot sukses gesing word. Hierdie inligting ondersteun ook die relatief beduidende persentasie respondente wat 'n voorkeur vir Gemengde aanbidding (30\%) en vir Kontemporêre aanbidding (25\%) het.

Die orrel word egter deur die meeste van die deelnemers aan die onderhoude beskou as óf die primêre musiekinstrument of 'n musiekinstrument wat saam met, of afwisselend met ander meer kontemporêre instrumente in die erediens gebruik moet word (GA). Hierdie is dus'n sterk aanduiding dat die gemeente geleidelik besig is om weg te beweeg van 'n TLGA na KA en GA. Onderhoude met die jonger deelnemers (15-25 jaar) het aangedui dat die orrel beskou is as 'n instrument wat nie in staat is om "vinnige" musiek te speel nie. 'n Deelnemer noem dat die orrel volgens haar/hom "die gemeente laat trek as hulle sing". Onderhoude met lidmate in die ouderdomsgroep 15-25 jaar het tog waardering getoon vir die plek van die orrel in die erediens en gevoel dat dit meer geskik is vir musiek tydens die erediens. Hulle was van mening dat die orrel nie 'n geskikte musiekinstrument is wat tydens 'voorsang' met ander meer kontemporêre instrumente gebruik moet word nie. 
Slegs $10 \%$ van die respondente het 'n voorkeur vir CA getoon. In die onderhoude het veral jonger lidmate genoem dat hulle deur middel van liggaamsbeweging, sang en musiek die Here wil loof en prys omdat “... ons voluit vir Jesus leef en Sy liefde soos vuur ons harte aan die brand steek”. 'n Deelnemer aan 'n onderhoud (in die ouderdomsgroep 40-50 jaar) is van mening dat "meervoudige spiritualiteit en meervoudige bediening" die gemeente sal pas. Hierdie persepsie verwoord die gevoel van die meeste deelnemers wat aan die onderhoude deelgeneem het, dit stem ook ooreen met die ingesamelde kwantitatiewe data wat daarop dui dat die gemeente 'n sterk voorkeur vir Gemengde aanbidding of "konvergensie" (30\%) en Kontemporêre aanbidding (25\%) het.

Die studie wys uit dat die gemeente ten opsigte van sang en musiek in die erediens 'n voorkeur tot balans tussen die amptelike liedere in die Liedboek en die vrye lied het wat 'n aanduiding is dat die gemeente verskuif in hul aanbiddingsprofiel vanaf 'n Tradisionele Liedboekgebaseerde aanbidding na 'n Kontemporêre sowel as Gemengde aanbiddingstyl. Hierdie waarneming word bevestig deur die beskouings van die ouer lidmate wat aan die studie deelgeneem het dat hulle naas die amptelike Liedboek ook ten gunste is van meer kontemporêre musiek en die vrye lied. Kwalitatiewe inligting wat tydens die onderhoude ingevorder is het aangedui dat die deelnemers nie ten gunste van 'n multisensoriese aanbiddingstyl (OA) is nie. Dit was veral die ouer lidmate wat OA binne 'n gereformeerde konteks as "vreemd" ervaar het. 'n Deelnemer het opgemerk dat OA "maklik kan ontaard in wanorde".

Die metode wat in die studie gevolg is het dit moontlik gemaak om die ingesamelde kwantitatiewe data in perspektief te stel en te interpreteer. Die voer van die onderhoude het as kwalitatiewe metode bygedra om ryk, grondige inligting te bekom. Die onderhoude het byvoorbeeld uitgewys dat baie lidmate terme soos charismaties soms foutief gebruik wanneer hulle bedoeling is om te verwys na 'n voorkeur vir meer kontemporêre musiek en sang en hulle nie met die gebruik van die term charismaties noodwendig'n voorkeur probeer aandui vir die manifestasies van die krag van die Heilige Gees nie.

Alhoewel die erediens moeilik in vaste kompartemente pas, bied die diverse modelle van aanbidding, soos Basden (2004) dit opgeteken 
het, 'n meganisme om die verskillende perspektiewe van aanbidding binne 'n gemeente beter te kan verstaan. Alhoewel Noord-Amerikaanse aanbiddingsmodelle gebruik is om die aanbiddingsprofiel van die gemeente Oosterlig te verstaan, sou 'n raamwerk wat gebaseer en geskik is vir die verstaan van aanbiddingsmodelle binne 'n Suid-Afrikaanse konteks, wat relevansie betref, waarskynlik van groter waarde kon wees.

Alle ouderdomsgroepe en veral die jonger lidmate moet betrek word om groter inspraak te hê in die skep van nuwe musiek en in die seleksie van die vrye lied - in samehang met gereformeerde beginsels. Die gemeente sal daarom moet besin oor die definiëring van sang en musiek waar al sy lidmate in lof en aanbidding tot God kan kom en, wat die jonger lidmate betref, moet voorsiening maak vir musiek en sang "wat die hedendaagse tiener in staat stel om binne sy of haar eie leefwêreld en verstaanswêreld, konkreet te antwoord op die openbaring van God in Christus en sy Woord" (Van Tonder 2001:77). Hierdie musiek mag nie onkrities van ander denominasies oorgeneem word nie, dit moet inhoudelik ooreenstem met die gereformeerde leer.

Die studie het getoon dat die Liedboek en die gebruik van onder andere die orrel as primêre musiekinstrument in die erediens ten opsigte van NG Oosterlig nie meer op sigself aan die diverse aanbiddingsbehoeftes van hierdie gemeente voldoen nie. Die orrel word steeds deur die meerderheid (ouer) gemeentelede beskou as 'n belangrike musiekinstrument wat deel van die liturgie moet vorm. Die gemeente sal daarom moet besin oor die plek van die orrel in musiek en sang en hoe dit saam met ander meer kontemporêre musiekinstrumente gebruik kan word. Wat sang betref sal die nodige veranderings ook aangebring moet word wat pas by'n KA en GA aanbiddingsprofiel waar meer insette van die jonger lidmate gelewer moet word. Die meerderheid lidmate val binne die ouderdomskategorie van 50 jaar plus en is tradisioneel behoudend ten opsigte van kerkmusiek en sang. Toekomstige vernuwing mag daarom nie by die ouer ouderdomsgroep in die gemeente 'n belewing van vervreemding tydens die erediens lei nie, maar sang en musiek wat in die erediens gebruik word, behoort aangebied te word dat dit meer raakvlakke met die leefwêreld van ook die jonger lidmate het. Soos reeds genoem, veranderinge wat oorweeg word moet in lyn staan met die gereformeerde beginsels van aanbidding, daarom geld Noordmans se waarskuwing dat daar maklik veranderinge aan die orde, 
rituele en simbole van die liturgie aangebring kan word terwyl onwetend dinge gekommunikeer word wat nie pas by gereformeerde beginsels nie. Daar kan nie na willekeur uit verskillende liturgiese tradisies geneem word onder die veronderstelling dat die kerk oor 'een erediens' beskik nie. Noordmans waarsku dat dit niks anders as "kultiese smokkelhandel" oor dogmatiese grense heen sou beteken nie (Du Plessis 2004:91).

Soos in hierdie artikel genoem dui die gereformeerde beginsels op 'n erediens wat ordelik moet verloop (Du Plessis 2004), prediking wat 'n sentrale plek in die erediens moet inneem (Kloppers en Dreyer 2003) en dat die erediens moet rus op 'n goed verantwoorde liturgiese orde met suiwer teologiese grondslag (Müller 1990). In hierdie verband kan byvoorbeeld die wyse waarop OA binne 'n Noord Amerikaanse konteks funksioneer, moeilik binne 'n gereformeerde tradisie geregverdig word omdat prediking (soos ook gemeentesang) nie 'n groot rol in OA speel nie. Dit geld ook vir die gereformeerde beginsel van orde binne die erediens wat volgens Morgenthaler verskeie handelinge insluit wat gelyktydig plaasvind want in OA doen alle aanbidders nie meer "the same thing at a time" (Morgenthaler 2004:240) nie. Du Plessis (2004:105) gebruik die term multisensoriese aanbidding, wat dui op eredienste met 'n multisensoriese liturgie wat in lyn staan met gereformeerde beginsels. Du Plessis (2004:105) se voorstelling van 'n multisensoriese aanbidding sal dus eerder geskik wees vir 'n Suid Afrikaanse konteks as OA.

Ten slotte kan genoem word dat Exploring the worship spectrum (Basden 2004) 'n oorsig oor die verskillende aanbiddingsperspektiewe en -style bied vanaf'n meer konserwatiewe en hoë kerklik-liturgiese tot 'n meer informele aanbiddingstyl en daarom die doel van hierdie studie as breë raamwerk kon dien. Soos reeds genoem, is 'n leemte in die studie dat die ses aanbiddingstyle op die perspektiewe binne 'n Noord-Amerikaanse konteks reflekteer en die werk gaan so ver terug as 2004 toe dit gepubliseer is. Daar is 'n behoefte aan navorsing wat deur gemeentes gebruik kan word as teoretiese onderbou vir studies soos hierdie binne 'n (Suid-) Afrikaanse konteks. Daar is betreklik min navorsing en literatuur beskikbaar wat handel oor musiek en sang binne 'n Suid-Afrikaanse konteks. Nieteenstaande die feit dat hierdie artikel 'n oorsig bied oor 'n ondersoek wat geloods is binne 'n spesifieke gemeente, kan die studie dien as verwysing vir soortgelyke studies binne'n Suid-Afrikaanse konteks. 
Figuur 1: Aanbiddingsprofiel van die NG Gemeente Oosterlig NG Gemeente Oosterlig

\section{Vraelys oor sang en musiekvoorkeure}

Beste lidmaat

Baie dankie dat u bereidwillig is om na die diens hierdie vraelys te voltooi.

- Skryf asseblief enige addisionele kommentaar op die agterkant van die vraelys.

- Die vraelys word anoniem beantwoord, moet verkieslik nie u naam op die vraelys skryf nie!

- Handig u voltooide vraelys by die kerk se deure in as u uitstap of vou die vraelys toe en plaas dit in die boekrakkie by u bank.

Merk u ouderdomskategorie met 'n X:

\begin{tabular}{|l|l|}
\hline OUDERDOM & MERK MET 'n X \\
\hline Tussen $15-25$ jaar & \\
\hline Tussen $26-35$ jaar & \\
\hline Tussen $36-50$ jaar & \\
\hline Ouer as 50 jaar & \\
\hline
\end{tabular}

Sleutel: Beantwoord elke vraag deur een van die volgende keuses met 'n X aan te dui:

\begin{tabular}{|l|r|}
\hline KIES EEN VAN DIE VOLGENDE ANTWOORDE: & WAARDE \\
\hline NEE ek stem BESLIS nie saam nie & 2 \\
\hline NEE ek stem nie saam nie & 3 \\
\hline Ek is onseker of ek het gemengde voelens oor die vraag & 4 \\
\hline JA ek stem saam & 5 \\
\hline JA ek stem BESLIS saam & 2 \\
\hline
\end{tabular}




\section{VRAELYS}

Gebruik bogenoemde sleutel om elk van die volgende stellings te beantwoord, Al die vrae moet asseblief beantwoord word. Dit behoort $\mathrm{u}$ nie langer as 4 minute te neem om al die vrae te beantwoord nie:

\section{Sleutel:}

\begin{tabular}{|c|c|c|c|c|c|c|}
\hline & $\begin{array}{l}\text { GEMEENTESANG EN MUSIEK MOET VOLGENS } \\
\text { MY SIENING ... }\end{array}$ & 1 & 2 & 3 & 4 & 5 \\
\hline 1 & $\begin{array}{l}\text { Daarin slaag om aan die meeste lidmate se musiek en } \\
\text { sangvoorkeure voorsiening te maak }\end{array}$ & & & & & \\
\hline 2 & Uit die Liedboek van die Kerk gesing moet word & & & & & \\
\hline 3 & $\begin{array}{l}\text { Nie vir ons as lidmate "aangebied" word asof ons } \\
\text { "verbruikers" is wat saam moet sing wat vir ons deur } \\
\text { 'n musiekleier of musiekgroep elke Sondag "opgedis" } \\
\text { word nie }\end{array}$ & & & & & \\
\hline 4 & $\begin{array}{l}\text { Lidmate help om deur die kragdadige werking van die } \\
\text { Gees stelselmatig nader tot God te beweeg }\end{array}$ & & & & & \\
\hline 5 & $\begin{array}{l}\text { Vir die meeste van die gemeentelede darem } \\
\text { "aanvaarbaar" wees }\end{array}$ & & & & & \\
\hline 6 & $\begin{array}{l}\text { Die primêre saak in die erediens wees, dis selfs } \\
\text { belangriker as die preek! }\end{array}$ & & & & & \\
\hline 7 & $\begin{array}{l}\text { Slegs op 'n spesifieke "plek", dit wil sê as deel van die } \\
\text { erediens orde, gesing word }\end{array}$ & & & & & \\
\hline 8 & $\begin{array}{l}\text { Lidmate so aktief betrokke maak by die werking van } \\
\text { die Gees dat hul selfs hul hande kan ophef }\end{array}$ & & & & & \\
\hline 9 & $\begin{array}{l}\text { Nie só belangrik in die erediens wees nie want as } \\
\text { postmoderne mens kan gelowiges ook op God fokus } \\
\text { deur deur byvoorbeeld wierook te ruik! }\end{array}$ & & & & & \\
\hline
\end{tabular}




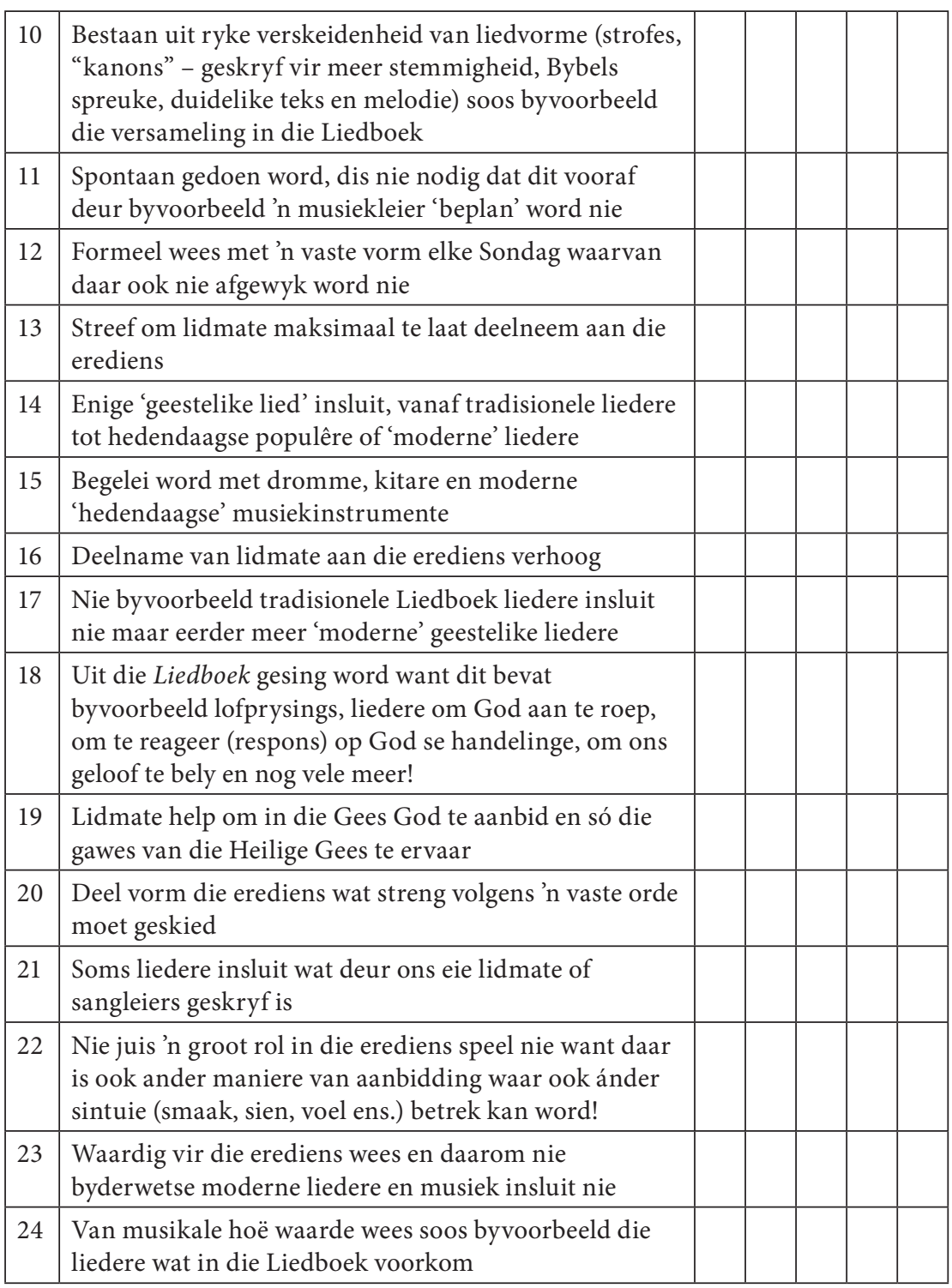




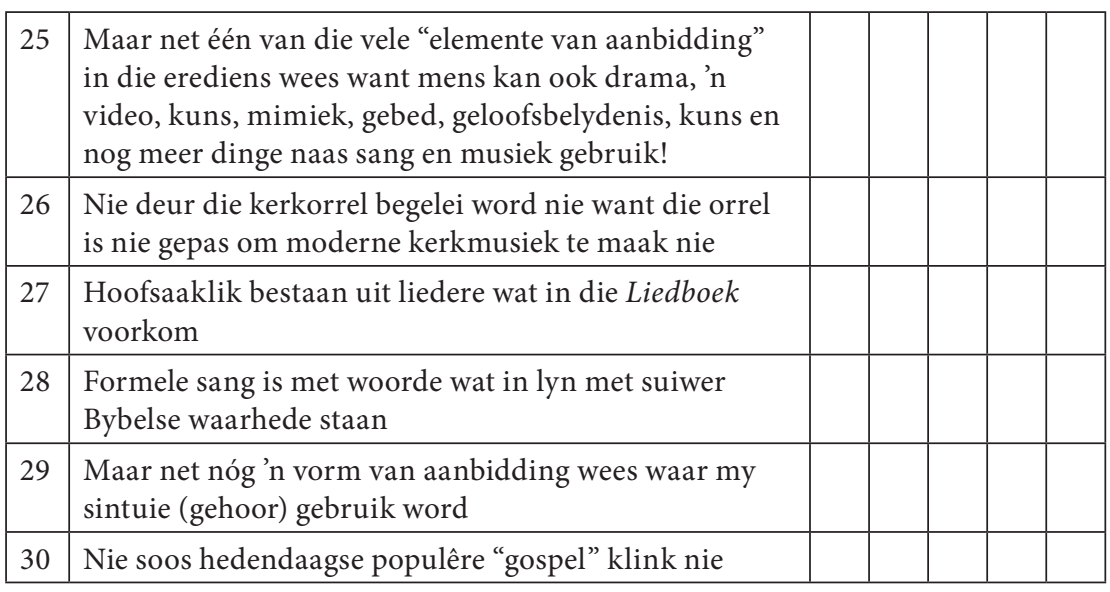

Skryf asseblief enige kommentaar of addisionele inligting oor sang en musiek hier neer

Baie dankie vir u bydrae

Studieleier

Dr Hans Brits 


\section{Bibliografie}

Barnard, A C 1985. Die erediens. Pretoria: NG Kerkboekhandel.

Basden, P A 2004. Exploring the Worship Spectrum: Six Views

(Counterpoints). Grand Rapids: Zondervan.

Best, H 2004. Traditional hymn-based worship. In Basden, P A (red).

Exploring the worship spectrum. pp. 59-75. Grand Rapids:

Zondervan.

Calitz, C J 2015. Landskap van gemeentesang in die Nederduitse

Gereformeerde Kerk aan die begin van die een-en-twintigste eeu:

Voorlopige verkenning. In die Skriflig. 49(1). 11 bladsye. [Intyds].

Beskikbaar: http://dx.doi.org/10.4102/ids.v49i1.1795.

Calitz, C J 2011. The free song (hymn) as a means of expression of the spirituality of the congregation with specific forcus on the situation of the Dutch Reformed Church in South Africa. Philosophiae Doctor Tesis. University of Pretoria.

Cilliers, J 1998. Die uitwysing van God op die Kansel: Inspirerende perspektiewe op die prediking - om God te sien en ander te laat sien. Kaapstad: Lux Verbi.

De Klerk, B J 1999. Vaartversnelling vra verdieping van ons liturgie. In die Skriflig, 33(3): 311-330.

Denscombe, M 2003. The good research guide: For small-scale social research projects. New York: Open University Press.

Dingemans, G D J 1996. Practical theology in the academy. A contemporary overview. The Journal of Religion, 76 (1): 82-96.

Du Plessis, I 2004. Multisensoriese Liturgie. MA verhandeling. Universiteit van Pretoria.

Firet. J 1987. Spreken als een leerling. Praktisch-theologische opstellen. Kampen: Kok. 
Horness, J 2004. Contemporary music-driven worship. In Basden, P A (red.). Exploring the worship spectrum. Grand Rapids: Zondervan. 99-116.

Johansson, C M 1998. Music and Ministry: a Biblical counterpoint. Peabody, Massachusetts. Hendrickson.

Kloppers, E C \& Dreyer T F J 1994. Liturgiese koorsang as wyse van kerklike verkondiging: 'n Prinsipiële besinning vanuit hermeneutieshomilitiese perspektief. HTS, 50(3): 583-609.

Kloppers, E C 2003. Verkondiging deur musiek: 'n Aspek van kreatiewe geloofskommunikasie. HTS, 59(1).

Liedboek van die Kerk. 2001. NG Kerk-uitgewers: Kaapstad.

McMillan, J H \& Schumacher, S 2001. Reseach in education: a conceptual introduction. New York: Addison-Wesley Longman.

Milo, D W L 1946. Zangers en Speellieden. Vlaardingen: Theologische Boekhandel.

Morgenthaler, S 2004. An emerging worhsip response. In Basden, P A (red.). Exploring the worship spectrum. pp. 131-230. Grand Rapids: Zondervan.

Pieterse, H 2011. Die reformatoriese kerklike landskap. In Vos, C \& Human, D. Vaste Rots op wie ek bou. pp. 37-52. Kaapstad: Lux Verbi.

Smit, C J \& Vorster, J M 2000. Die GKSA en sy gereformeerde identiteit: Kan dit behou word in 'n postmoderne gemeenskap? Potchefstroom: In die Skriflig, 34(4): 515-533.

Smit, D. 2009. Ontdek die aard van die gereformeerde diens. In Wepener, C en Van der Merwe J. Ontdekkings in die erediens. pp. 87-108.

Van der Ven, J A 1988. Practical theology: from applied to empirical theology. Journal of Empirical Theology, (1):7-27.

Webber, R 2004. Blended worship. In Basden, P A (red.). Exploring the worship spectrum. pp. 175-191. Grand Rapids: Zondervan. 
Wepener, C 2009. From fast to feast: A ritualliturgical exploration of reconciliation in South African cultural contexts. Leuven: Peeters.

Williams, D 2004. Charismatic worship. In Basden, P A. Exploring the worship spectrum. pp. 139-152. Grand Rapids: Zondervan.

Zahl, P F M 2004. Formal-liturgical worship. In Basden, P A. Exploring the worship spectrum. pp. 23-26. Grand Rapids: Zondervan. 